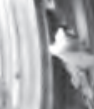

ting

te. 91 .

it

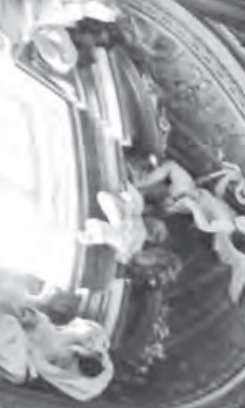

क्षेत 8

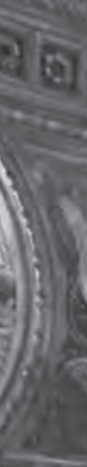

E.

$x+x=$
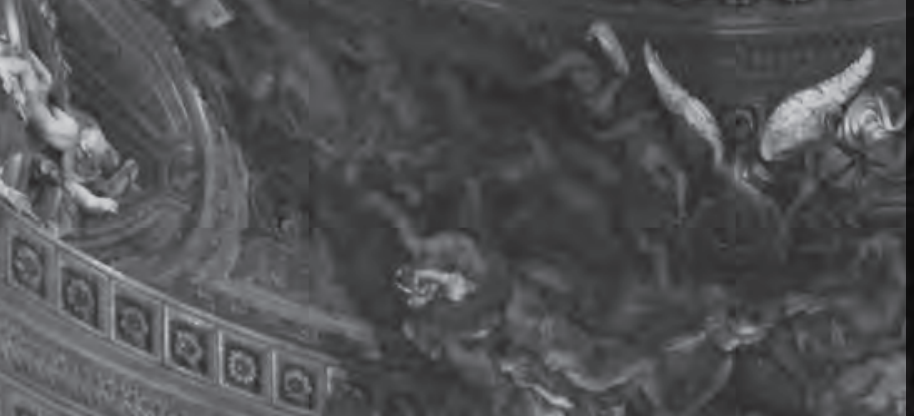

52

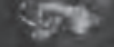

8

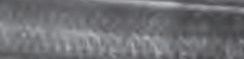

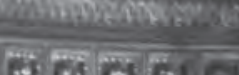

2. 0 की

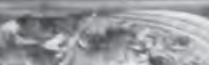

-

25 me
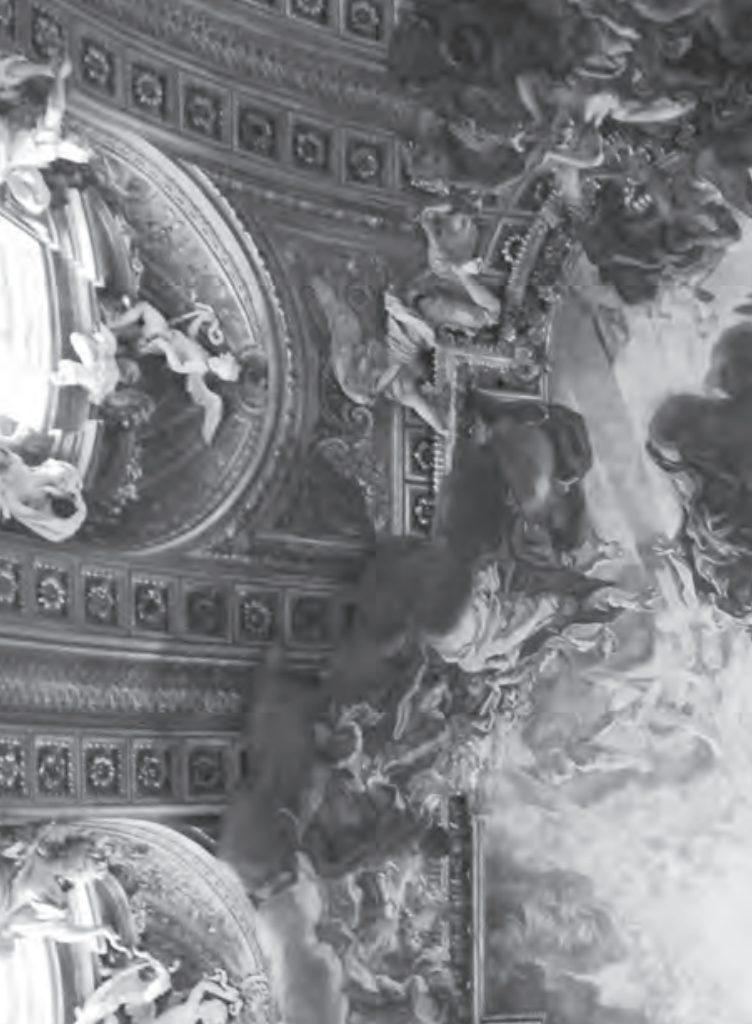

rats

25
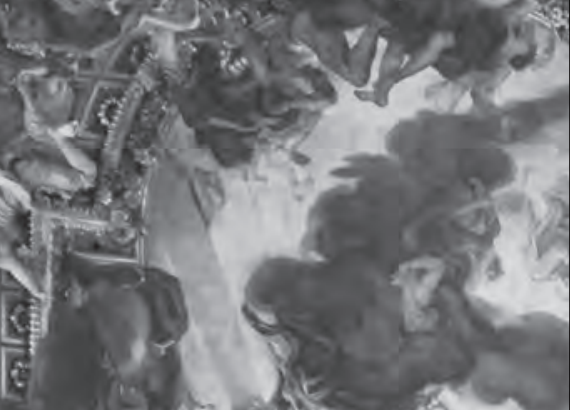

1. Rodrigo Baeta é doutor e mestre pelo Programa de Pós-graduação em Arquitetura e Urbanismo da Universidade Federal da Bahia (PPGAU UFBA); especialista pelo Curso de Conservação e Restauração de Monumentos e Sítios Históricos (IX CECRE UFBA) e pelo Curso Ciudades y Viviendas de Iberoamérica, oferecido pelo Centro Nacional de Conservación, Restauración y Museología (Cencrem), Havana, Cuba; arquiteto formado pela Escola de Arquitetura da Universidade Federal de Minas Gerais (EA UFMG); professor adjunto da Faculdade de Arquitetura da Universidade Federal da Bahia (FA UFBA). 


\title{
CRISE, PERSUASÃO E O UNIVERSO CULTURAL DO BARROCO
}

CRISIS, PERSUASION AND THE CULTURAL BAROQUE UNIVERSE

Rodrigo Baeta ${ }^{1}$

\begin{abstract}
Resumo
A arte barroca perseguiria, incondicionalmente, a elaboração de um discurso de qualidade altamente retórica com o objetivo de alcançar a meta final da persuasão. As motivações que impulsionariam o exercício da persuasão estariam vinculadas à construção de estratégias de propaganda empreendidas pela Igreja e pelos governos autoritários, em crise constante por causa do colapso econômico, político, mas principalmente devido às revoltas sociais que se desenhavam na esfera das sociedades seiscentistas, um panorama conturbado que se estenderia à próxima centúria. Por meio do artifício da imaginação e da fantasia, logo, da dramatização e da teatralização das expressões visibilísticas, os artistas, comprometidos com as monumentais estruturas de poder, construiriam um sedutor discurso de alto teor retórico que revelaria, simbolicamente, o caráter grandioso da Igreja e dos impérios absolutistas, dirigindo as massas a um comportamento adequado de apoio e subordinação aos governos.
\end{abstract}

Palavras-chave: Barroco; crise; persuasão.

\begin{abstract}
Baroque art would chase, unconditionally, the development of a highly rhetorical quality speech in order to pursue the ultimate goal of persuasion. The motivation that promotes the exercise of persuasion would be linked to the construction of advertising strategies undertaken by the Church and by authoritarian governments, in constant crisis due to the economic collapse, political, but mainly due to social upheavals that drew in the realm of seventeenth-century societies - a troubled landscape stretching to the next century. Through the device of the imagination and fantasy, so the drama and theatricality of the visibilistics expressions, the artists, committed to the monumental structures of power, build a high content of seductive rhetoric speech which reveal, symbolically, the grandiose scale of the Church and the absolutist empires, driving the masses to support appropriate behavior and subordination to the government.
\end{abstract}

Keywords: Baroque; crisis; persuasion. 
Nós acreditamos (e esta será a nossa tese) que o Barroco é uma cultura que consiste na resposta dada, aproximadamente durante o século XVII, pelos grupos ativos em uma sociedade que entrou em dura e difícil crise, relacionada com flutuações críticas na economia do mesmo período. [...] Durante aquela fase, seus transtornos econômicos foram mais estudados e são mais bem conhecidos. Agora, faz alguns anos, já se começa a estudar as alterações sociais que surgem por todos os lados. Porém, não se trata simplesmente de fenômenos isolados ou intermitentes, de mal-estar dos povos, nem das aparentes explosões, de raio maior ou menor, em que se manifestam, e sim o fato de que a centúria do Barroco foi um longo período de profunda crise social, cuja própria existência nos permite compreender as especificas características daquele século (MARAVALL, 2007, p. 56) (tradução nossa).

Em seu consagrado livro intitulado La cultura del Barroco (primeira edição de 1975), provavelmente a mais completa investigação conduzida sobre o universo cultural do período, o historiador espanhol José Antonio Maravall (1911-1986) desenvolveria uma tese que guardaria seus fundamentos em muitos aspectos tratados no estudo de 1929, Storia dell'età barocca in Italia, do filósofo italiano Benedetto Croce (1866-1952), especialmente a ideia de que os tempos barrocos marcariam uma época de profunda crise econômica e social. O texto moralista de Croce se resumiria praticamente à avaliação do fenômeno no território italiano, apesar do autor traçar seu juízo condenatório de forma a viabilizar a "exportação" dos princípios "antiéticos" e "imorais" do movimento para todas as manifestações consideradas barrocas e dispersas pelas mais diversas realidades; de igual modo, o professor Maravall buscaria um entendimento absoluto e unitário do conceito de cultura barroca, mesmo tendo desenvolvido sua pesquisa privilegiando, essencialmente, fontes espanholas de averiguação histórica (mas assegurando que a Espanha seria apenas mais um entre tantos contextos imersos nesse mesmo espírito que teria sido deflagrado no Ocidente, em finais do século XVI).

Os documentos que desvelariam o caráter dessa época de tensão foram perseguidos, principalmente, por meio da análise do conteúdo impresso na literatura seiscentista, no Siglo de oro espanhol, nas informações capturadas no desenrolar das suas narrativas, dispersas em suas estrofes, contempladas no corpus da redação e que, implicitamente, tratavam das características universais que o autor viria a apontar para a cultura barroca. Portanto, nos tratados de política, economia, comportamento, assim como na própria poesia, no teatro, na prosa e nas novelas espanholas, seria possível detectar indícios dos conflitos gerados na sociedade barroca, bem como descobrir pistas que desvendassem as respostas que os governantes dariam à conjuntura de crise. Por isso, não seria a qualificação estética dessas obras que teria mobilizado, prioritariamente, as investigações de Maravall, mas aquilo que estaria subentendido nas estrofes, parágrafos, frases e nas palavras dos textos apreciados, e que serviria para demonstrar a fisionomia da era barroca. 
Nesse sentido, Maravall daria continuidade à tendência da crítica estabelecida após a década de 1930 e que decretava - ao superar os princípios debatidos pelo escritor e crítico de arte catalão, Eugenio D'ors (1881-1954), nas conferências de Pontigny², juízo publicado no seu livro, lançado originalmente em francês, em 1935, denominado Du Barroque (D'ORS, 1968) - o abandono definitivo da ideia do fenômeno como uma constante temporal que vinha se repetindo, invariavelmente, durante toda a existência da civilização. Além disso, reforçava uma disposição que viria a ser muito significativa nas teorizações elaboradas nos últimos anos sobre o período e que declarava que o Barroco, apesar de ser um mero conceito de época, envolveria todo o cenário social, econômico, político, religioso de finais do século XVI até finais do século XVII. ${ }^{3}$ Ou seja, não seria o caso simplesmente de compreendê-lo como um reflexo da arte frente à situação de crise que se constituía ao seu redor; os próprios acontecimentos trágicos a que a sociedade estava submetida (colapso econômico, conflitos religiosos, guerras incessantes, várias pestes, decréscimo populacional, abandono do campo, inchaço das cidades, revoltas sociais, falência das antigas instituições) eram basicamente elementos barrocos, indissociáveis da concepção e da produção da arte. Ao contestar o signo de decadência que Croce endossava para a cultura barroca, o crítico de literatura Andrea Battistini escreveria sobre a crise do Seicento em seu livro /l Barocco, publicado pela primeira vez no ano 2000:

Mais do que sinal de decadência, o Barroco é o testemunho de uma profunda crise antropológica que produziu agitações e desequilibrios e de onde nasceu uma situação histórica que viu o progressivo deslocamento do baricentro político da Itália e do Mediterrâneo para as latitudes mais setentrionais. A guerra dos Trinta Anos, uma das mais terriveis acontecidas no Velho Continente, se abateu sobre a Europa com o trágico séquito de carestias, saques, pestilências, crises demográficas, gerando instabilidades e conflitos sociais sem precedentes, cuja revolta de Masaniello, ocorrida em 1647, é só uma das tantas sedições que perturbaram a vida do Seicento, uma idade assinalada por grandes revoltas, sobretudo camponesas, devidas ao aumento da pressão dos proprietários de terra, sempre mais levados a incrementar as despesas militares e de representação, por junta improdutiva. [...] Mas, não menos perturbador foi, ao lado de uma assustadora miséria que difundiu por todo lado um sentimento de insegurança e precariedade, a contestação de um sistema de saberes e de valores no qual a cultura europeia havia, por tantos séculos, encontrado sua segurança (BATTISTINI, 2002, p. 22-23) (tradução nossa).

No cenário da crise, no que tange aos conflitos políticos e religiosos entre as nações, o século XVII foi uma época que teve inúmeras guerras sangrentas. O espetáculo desolador era incrível. As guerras traziam as pilhagens, já que os soldados tinham direito ao espólio, aos saques das cidades invadidas, situação na qual poderiam retirar seu único ganho significativo. Eram comuns os abusos dos combatentes, que matavam, torturavam, violentavam, humilhavam a população civil, além de usurparem os bens das comunidades em geral. Nos insalubres ambientes sitiados e
2. As Décades de Pontigny eram reuniões de intelectuais europeus que aconteciam todo verão, após o ano de 1910, nas ruínas da abadia cisterciense de Pontigny. A abadia havia sido comprada pouco antes pelo professor Paul Desjardins (1859-1940), que a abriu para discussões diversas sobre o humano e o divino, num ambiente de tolerância incomum na Europa do segundo quartel do século XX.

3. "O Barroco deixou de ser, para nós, um conceito de estilo que possa repetir-se e que, de fato, supõe-se que tenha se repetido em múltiplas fases da história humana; veio a ser, em franca contradição com o que foi dito anteriormente, um mero conceito de época. Nossa investigação acaba apresentando-nos o Barroco como uma época definida na história de alguns países europeus, cuja situação histórica guarda, em certo momento, estreita relação, independentemente das diferenças entre eles.

Consequentemente, a cultura de uma época barroca pode ser encontrada também, e com certeza o foi, em países americanos sobre os quais repercutiram as condições culturais europeias desse tempo" (MARAVALL, 2007, p. 23) (tradução nossa). 
degradados pelos conflitos, as pestes dizimavam a todos, bem como a fome proveniente do corte de suprimentos e víveres. Para além disso, segundo diria o historiador inglês Geoffrey Parker (2005, p. 31), em seu texto de 1991, intitulado // soldato, a morte era quase uma certeza para quem estava envolvido nos confrontos: calcula-se que um soldado em cada quatro ou cinco morriam no front todos os anos e, em determinadas guerras, essa porcentagem seria bem maior (ou seja, poucos efetivamente voltavam após alguns anos de serviço).

Nesse cenário de instabilidade política e social, em que, para além das inúmeras guerras, quatro pestes, crise de suprimentos alimentícios, fome, revoltas populares nas cidades e no campo, perseguições religiosas, o pavor proveniente do combate às insurreições, bem como a miséria absoluta aterrorizavam a população europeia e preocupavam seus governantes, poderiam ser claramente identificadas, a todo instante, as mais diversas manifestações do espírito barroco: na pintura, escultura, arquitetura, urbanística, literatura, poesia, música, teatro; igualmente seria legítimo afirmar a possibilidade de vislumbrar, na sociedade do século XVII, uma economia e uma política que poderiam ser compreendidas como barrocas, uma arte da guerra barroca, uma atitude filosófica frente ao mundo e um comportamento social barrocos, uma ciência barroca, uma espiritualidade barroca. Toda a dimensão cultural estaria, consequentemente, conectada à crise que se estabeleceu; era, na verdade, uma reação, muitas vezes consciente, à difícil conjuntura que se instalava no mundo ocidental, como revelaria o historiador italiano Rosario Villari, na coletânea, L'uomo barocco, organizada por ele em 1991:

Os europeus do século XVII tiveram também uma ideia particularmente dramática do período em que viveram e conseguiram transmiti-la aos seus sucessores: século de ferro, mundus furiosus, era de tumultos e agitações, opressões e intrigas, em que "homens transformados em lobos se comem uns aos outros," época de desordem, de destruição, de arruinamento da hierarquia, de fantasias; época de grandes tensões, em suma, frequentemente consideradas negativas, em vez de fases necessárias para se atingir um maior equilíbrio social e político e uma mais profunda e abrangente capacidade criativa (VILLARI, 2005, p. IX) (tradução nossa).

Mas qual seria a relação da crise despertada no século XVII com a nova poética que a arte iria perseguir a partir de então? Para Maravall (2007, p. 63), se a crise econômica não chegou a preencher ininterruptamente todo o período, e acabaria se extinguindo antes mesmo do final da centúria, a consequente crise social proveniente do colapso que se instaurou nas finanças teria condenado a Europa e as colônias sob sua influência a inúmeras adversidades durante todo o século XVII e grande parte do XVIII. As contínuas anomalias sociais provenientes da difícil conjuntura econômica já estariam consolidadas nas últimas décadas do século XVI; a longa duração da crise e seu nascimento precoce teriam oferecido, consequentemente, tempo e substância suficientes para que as estruturas de poder fossem alertadas, na próxima centúria, para a necessidade de se buscar soluções e respostas às desventuras. 
Não obstante, as maiores catástrofes que afligiam a estabilidade dos governos ultrapassavam o problema do enfrentamento entre nações, as guerras originárias de disputas por territórios ou deflagradas por conflitos supostamente religiosos. Para além desses fatores, os príncipes se preocupavam, especialmente, com as revoltas das classes menos favorecidas: a turba que, levando uma vida absolutamente miserável, rebelava-se a todo instante no campo e principalmente nas cidades (antecipando as insurreições que aconteceriam nos setecentos e nos oitocentos). A resolução política encontrada para sanar essas perigosas patologias, para amenizar a insegurança e a instabilidade geral que tomavam conta da administração pública, foi a reunião dos pequenos territórios das antigas nações nos poderosos e extensos Estados nacionais. E para a administração dessas grandiosas estruturas de poder, o regime de governo escolhido, na maioria das vezes, foi o do absolutismo monárquico, sistema tirânico que propunha o controle irrestrito das sociedades pelo Estado; um Estado fundado na competência única da figura do rei, do imperador.

Portanto, mesmo nas nações sob forte influência da Igreja, ou governadas efetivamente por ela (como acontecia nos Estados Pontifícios), por causa do caráter abertamente político da instituição e do poder totalitário com que os religiosos, ou o próprio Papa (no caso específico de Roma, do Lácio. e das áreas sob seu domínio), comandavam seu território, não estaria excluída a tese de que o mecanismo essencial da cultura barroca era impulsionado pelo sistema absolutista. Talvez, não desconsiderando a importância fatal que a religião contemplava nos séculos XVII e XVIII, não recusando a condição de primeira ordem que a Contrarreforma sustentava (e ainda sustentaria por muitas décadas) nas grandes monarquias ligadas ao papado romano, não se deveria entender o Barroco como produto da Reforma católica, e sim compreender a atuação da Igreja como ação integralmente associada à cultura absolutista barroca contrariando as ideias defendidas por Werner Weisbach (18731953) no estudo, publicado em 1921, Barock als Kunst der Gegenreformation. ${ }^{4}$ Ou seja, a Igreja romana também era uma estrutura que detinha um poder absoluto, mesmo estando, muitas vezes, relacionada a outras organizações do domínio laico. Como estrutura autoritária de comando, revelaria objetivos idênticos àqueles vislumbrados na administração dos Estados nacionais (logo, o problema da Igreja não era substancialmente religioso, mais essencialmente político).

E esses objetivos monárquico-absolutistas fundamentavam-se no ato de manutenção da ordem vigente: logo, em aparente paradoxo com o arrojo, a extravagância e o ineditismo que a arte, a arquitetura, a literatura, a música adotavam, a cultura barroca se apresentaria como um fenômeno inteiramente conservador. O sistema político de rigoroso controle social objetivava a conservação irrestrita da organização estamental e do aparelho econômico que impulsionava as nações; a pirâmide de classes (na qual a realeza imperava absoluta na ponta, seguida logo abaixo pela aristocracia, depois pela burguesia que se consolidava, e com a gigantesca base se configurando como a melancólica massa da plebe desfavorecida) resgatava em parte os tradicionais esquemas de ordenação da coletividade, provenientes de longínquos tempos da Idade Média.
4. Aqui foi contemplada a excelente versão espanhola de Enrique Lafuente Ferrari, El Barroco, arte de la Contrarreforma (WEISBACH, 1948). 
Os avanços na estrutura social derivados dos séculos do Renascimento e do Maneirismo, particularmente a inovação no sistema de direitos civis proveniente da natureza independente das comunas (já uma realidade em finais da idade média) seriam substituídos pelo retorno a uma economia e a uma classe dominante ligadas à aristocracia: uma nobreza muitas vezes de sangue, senhorial; outras vezes burguesa, de recente nobilitação, favorecida pelo enriquecimento da classe média urbana, pela importância que guardava para a economia do Estado, e pelo apoio incondicional que dava ao monarca (pois a estabilidade do governo contribuía para seu enriquecimento). Contudo, o rei acabaria sempre privilegiando a nobreza de nascimento, de direito inato, já que a aristocracia rural viria a deter o controle sobre os rumos da economia, comandaria o grosso das finanças que impulsionavam a nação (além do fato de o imperador se considerar o primeiro dos nobres, reforçando o caráter conservador da economia e do sistema de governo).

Não obstante, a relação do rei com os senhores de terra e, consequentemente, com as províncias distantes, mudou consideravelmente quando a aristocracia se rebaixou a um simples instrumento de apoio ao monarca, sem aquele poder ancestral que detinha sobre seus domínios (que estavam perdendo rapidamente a autonomia). Foi uma realidade arduamente assimilada pela nobreza, que chegaria a promover muitos levantes contra o governo central, insurreições deflagradas em decorrência da insatisfação dos senhores com a posição inferior que inevitavelmente estavam assumindo frente às suas regiões, assim como pela relação fragilizada que as províncias passavam a ostentar em relação à capital imperial. A plebe frequentemente era mobilizada como massa de manobra, como "bucha de canhão" da nobreza revoltosa; mas, sucessivamente, os movimentos eram coibidos com eficiência e muita violência, e tanto os nobres como a turba eram castigados com absoluto rigor, com torturas, agonias e execuções.

Porém, a aristocracia rebelde, que não aceitava as novas imposições do Estado absolutista, era seguramente uma minoria (a maior parte se resignava à obediência cega ao rei). Na verdade, para a sociedade barroca, os nobres eram nada mais que elegantes e refinados membros da corte: seus gestos airosos, mas subservientes, exibiam sua obediência e veneração à figura do imperador (e não era em vão). Arnold Hauser (1998), em seu estudo clássico de 1951, Sozialgeschichte der Kunst und Literatur, ${ }^{5}$ demonstrou como a submissão da aristocracia rural ao novo sistema político era compensada pelos inúmeros privilégios que o monarca ofereceria à classe senhorial. E esses benefícios não eram contemplados por simples reconhecimento da sua casta, pelo direito de sangue dos senhores. Era uma forma de compensação das perdas que haviam sofrido para o governo central e para as nobilitações da burguesia; regalias também concebidas para evitar aquelas possíveis rebeliões contra o Estado absoluto.

Logo, para a conservação dessa tradicional estrutura de mundo e para o afastamento de qualquer risco de inovação na organização estamental da sociedade (as revoluções devidas à massa de miseráveis e de indigentes, muitas vezes manipulada por aristocratas e burgueses insatisfeitos) a cultura barroca (nas figuras do
5. Aqui se contemplou a versão em português denominada História social da arte e da literatura, traduzida do alemão por Álvaro Cabral (HAUSER, 1998).

Cadernos de Arquitetura e Urbanismo, v.18, n.22, $1^{0}$ sem. 2011 
Estado e da Igreja absolutistas) teria lançado mão de dois instrumentos muito diversos, quase opostos, mas profundamente eficazes, de controle, de direção.

O primeiro aparelho de controle revelar-se-ia na imediata repressão das insurreições por meio do uso da força bruta, da violência, do castigo. Os governos autoritários mantinham vários mecanismos de vigia para detectar possíveis movimentos de contestação da ordem, bem como sustentavam organizações militares ou paramilitares, mercenários ou mesmo soldados de outras nações, treinados para a implacável contenção das revoltas. Também essenciais eram as estratégias desenvolvidas para a instauração do terror, táticas que impulsionavam a severa punição dos idealizadores e dos participantes das revoluções (sempre um espetáculo público de tortura, tormento, mutilação, execução dos insurgentes). Mas também a Igreja católica elaborou com absoluta competência seu instrumento legal de combate aos infiéis, de condenação daqueles que blasfemavam, de castigo e eliminação dos que, supostamente, voltavam-se contra a instituição, contra a ordem: a Inquisição (particularmente a espanhola) foi um cruel conselho composto para conter as heresias contra a Igreja romana, com a frequente utilização, durante e após os julgamentos, dos artifícios da tortura e da execução dos condenados, sempre com métodos atrozes (espalhando o medo e o pavor nas populações dos Estados católicos). Para além desse fato, muitas vezes, em função da absoluta eficiência em condenar qualquer indivíduo que fosse uma ameaça, o Tribunal do Santo Ofício também foi utilizado para perseguir e extinguir inimigos do Império, já que, naquele período, a Igreja estava vinculada, indissociavelmente, ao governo das nações absolutistas católicas (o que, frequentemente, promoveria a contestação da legitimidade espiritual da Inquisição).

Mas os governos e a própria Igreja tinham consciência de que só uma estrutura competente de repressão física não era capaz, isoladamente, de abafar as agitações de uma sociedade em total situação de crise. Nesse sentido, a cultura barroca buscaria outro método, ainda mais eficaz, de controle das massas e que estaria, desta vez, diretamente ligado às artes, à arquitetura, à urbanísti$\mathrm{ca}$, à cidade, à poesia, literatura, música, ao teatro: um método baseado na ação de conquista, de sedução, de convencimento dos súditos e dos fiéis por meio do apelo aos sentimentos, aos afetos, às emoções. As manifestações estéticas passariam a servir como atraente propaganda dos governos e da Igreja contrarreformista, dirigida ao encantamento tanto dos doutos como da mais humilde e ignorante massa populacional. Para a cultura barroca, as artes passariam a ser um assunto religioso e de Estado, máquina dirigida à distração e principalmente à persuasão, com a finalidade última da efetiva conservação da estratificação social, da preservação da tradicional ordem econômica e religiosa estabelecidas. Maravall sintetizaria a problemática:

Eis aqui, portanto, o panorama social que explica o desenvolvimento de uma cultura nos termos que procuramos estabelecer: determinados grupos elevados e distinguidos, que tratam de manter e de aumentar privilégios e riquezas, cuja conservação se vê ameaçada pela crise - à parte os inconformismos que esta, por sua vez, suscita 
-, os quais contam com uma massa de poder social e de recursos políticos para consegui-los, e, abaixo, um estado plano ao qual chegam os açoites das pestes, da pobreza, da fome, da guerra; que, por sua própria procedência social, não se pode limitar à vil resignação das populações mais baixas; que, em consequência, mostra reiteradamente atitudes de protesto [...]. Para calar tais mostras de desassossego, pensando que os recursos de repressão física talvez não bastassem, os poderosos se veem obrigados a ajudar e a servir-se daqueles que Ihes podem proporcionar os recursos eficazes de uma cultura; de uma cultura na qual predominarão, coerentemente, os elementos de atração, de persuasão, de compromisso com o sistema, a cuja integração defensiva se trata de incorporar a essa massa comum que, de qualquer modo, é mais numerosa que os dilatados grupos privilegiados e podem ameaçar sua ordem (MARAVALL, 2007, p. 88-89) (tradução nossa).

Mais uma vez, é possível voltar-se para o pensamento pioneiro de Benedetto Croce quando afirmava, na década de 1920, que as expressões barrocas absorviam, inevitavelmente, um sentido prático, que as obras elaboradas pelos pintores, escultores, arquitetos, literatos, serviam a um fim utilitário, que essa finalidade se equivaleria, decididamente, àqueles recursos de atração e persuasão os quais foram incentivados pelas classes dominantes (e que, para Maravall, constituiriam parte essencial da cultura barroca). O que não se poderia mais aceitar, e já tinha sido rejeitado há tempos, seria o juízo negativo exposto pelo filósofo italiano fundado no princípio da impossibilidade de apreensão das manifestações do período como legítimas representantes do universo das artes e da poesia, por seu suposto afastamento frente aos reais desígnios da contemplação artística, em prol do simples exercício do estupor, da busca da maravilha, visando "sordidamente" o convencimento, a sedução: "Que se diga 'idade barroca' e arte 'barroca'; contudo, não se perca nunca a consciência de que, a rigor, aquilo que é verdadeiramente arte não é jamais barroco, e aquilo que é barroco não é arte" (CROCE, 1993, p. 60) (tradução nossa).

$\mathrm{Na}$ verdade, o grande valor da arte barroca residiria, justamente, na sua condição, assumida confessadamente, de técnica gestual da persuasão, de estratégia de comunicação que visava, sem dúvida, à conservação da ordem tradicional por meio da contenção passiva das massas pela distração, pelo envolvimento, pelo encantamento que as obras propunham ao receptor (evitando os mecanismos de repressão pela violência).

Por isso, o grande crítico italiano de arte, Giulio Carlo Argan (1909-1992), elaboraria a tese que viria a estabelecer o compromisso do fenômeno barroco com a prática da retórica. Os artistas, poetas e ainda os políticos, os governantes, os pregadores, os missionários dos séculos XVII e XVIII haviam despertado para o problema de se conhecer a natureza humana e as características dos grupos sociais, para favorecer a construção de um discurso eficiente para a conquista das mentes e dos corações, que contribuísse para dirigi-los; por isso a cultura barroca teria sido a primeira cultura de massa do mundo moderno (MARAVALL, 2007, p. 176). Portanto, além do artista e da obra, era preciso 
considerar um terceiro elemento: o fruidor, que representava o objetivo último de toda experiência estética do Barroco.

Não que antes do século XVII os artistas deixassem de levar em conta o público, pois a arte sempre teve por finalidade sensibilizá-lo, comovê-lo. A diferença é que os renascentistas e os maneiristas frequentemente buscavam exportar o seu sentimento por meio da expressão artística (uma atitude que expunha o desejo dos criadores de revelar a emoção sincera que sofriam em relação às vicissitudes do mundo), e almejavam que o receptor absorvesse esse sentimento. Já os agentes da cultura barroca não se empenhariam (mais ainda, nem mesmo se preocupariam) em proclamar na composição estética aquilo que apreendiam quando contemplavam a natureza, o Universo. O esforço estaria todo concentrado na tática de proporcionar ao fruidor as mais diversas sensações, derivadas das necessidades de persuasão que aquela obra deveria satisfazer (o que denotava um afastamento do papel da arte em expressar os sentimentos que viessem do interior, da alma do artista). Uma intensa cumplicidade da produção estética com o público, com os apreciadores era deflagrada, e o artista canalizava suas potencialidades para desenvolver mecanismos de atração concebidos para agitar a mente dos espectadores. Por isso, a arte barroca era, para Argan, uma técnica retórica de comunicação, minuciosamente desenvolvida para agitar o lado mais emotivo das mentes dos indivíduos; cuidadosamente idealizada não para representar um conceito de universo e de natureza, uma ideia sobre o devir, sobre a existência humana, mas, em oposição, com a finalidade última e essencial de persuadir (figuras 1 e 2). É o que expunha o crítico italiano em seu ensaio La "Rettorica" e l'arte barocca, publicado em 1954:

É claro que, para a validade ou eficácia, aliás, para a própria existência da arte, desde já, faz-se necessário, além do artista e da obra, um terceiro elemento, um ouvinte ou um observador, um público: a condição, precisamente, do discurso demonstrativo. [...] Mais precisamente, se o escopo do artista era, no passado, fazer o receptor ver e provar aquilo que ele mesmo tinha visto e provado [...], e consequentemente, reproduzindo no receptor a condição do artista, agora o receptor é verdadeiramente um outro, e o artista já não se esforça nem a ver nem a sentir, mas apenas em fazer ver e sentir por meio de uma técnica que, na condição de artista, Ihe é própria. "Materiam superat opus," ou seja, o pintor quer suscitar maravilha; mais ainda que recorrer a "coisas novas e estranhas," ele deve buscar "tornar sua obra maravilhosa pela excelência da maneira" (ARGAN, 1986, p. 20-21) (tradução nossa).

Por extensão, não só o pintor queria suscitar a maravilha, mas também o poeta, o arquiteto, o urbanista, o cenógrafo, o compositor, e, para isso, seria desenvolvido um intenso processo de especialização no ramo das artes e da cultura de massa no geral, inédito no modo radical como foi conduzido. Consequentemente, a cultura barroca determinaria um enorme incremento nas possibilidades de se conceber as mais diversas técnicas da retórica e da persuasão: tantos gêneros específicos de pintura, tantos de poesia e literatura surgiriam; da mesma forma, a arquitetura e o espaço urbano assimilariam inúmeras e distintas 
funções devidas à sua condição como artifício de comunicação; também o teatro, a cenografia, a arquitetura efêmera, as grandes festas e encenações urbanas seriam essenciais para o exercício da conquista, assim como as inúmeras possibilidades de expressão musical. Cada manifestação exigiria uma técnica específica de oratória, uma construção retórica própria que, por outro lado, não haveria de pressupor um compromisso com nenhuma estrutura de poder específica, mas que poderia servir como mecanismo retórico orientado a todo e qualquer sistema autoritário que imperasse nos séculos XVII e XVIII.

Mas, da mesma forma que era impositivo que o artista elaborasse seus planos para promover a conquista, a sedução, o convencimento, o espectador (como uma via de mão dupla) também deveria deixar-se persuadir: o receptor que apreendia as manifestações estéticas do Barroco precisaria entregar-se ao "flerte", ao jogo da atração, deveria estar aberto à "preleção" retórica. Ao mesmo tempo, o artista deveria acreditar na força e na utilidade do processo comunicativo, para poder construir suas estratégias de persuasão.
Figura 1 (página ao lado) • Abóbada da nave da Igreja II Gesù, com o afresco Trionfo del Nome di Gesù, pintado entre 1674 e 1679 por Giovanni Battista Gauli (1639-1709), conhecido como

II Baciccia. A pintura trompe-l'œil das faces internas das abóbadas das igrejas com cenas bíblicas ilusionisticamente abertas para o céu seria um dos mais poderosos artifícios de apelo persuasivo na cenografia barroca dos templos católicos. Fonte: fotografia do autor, 2011

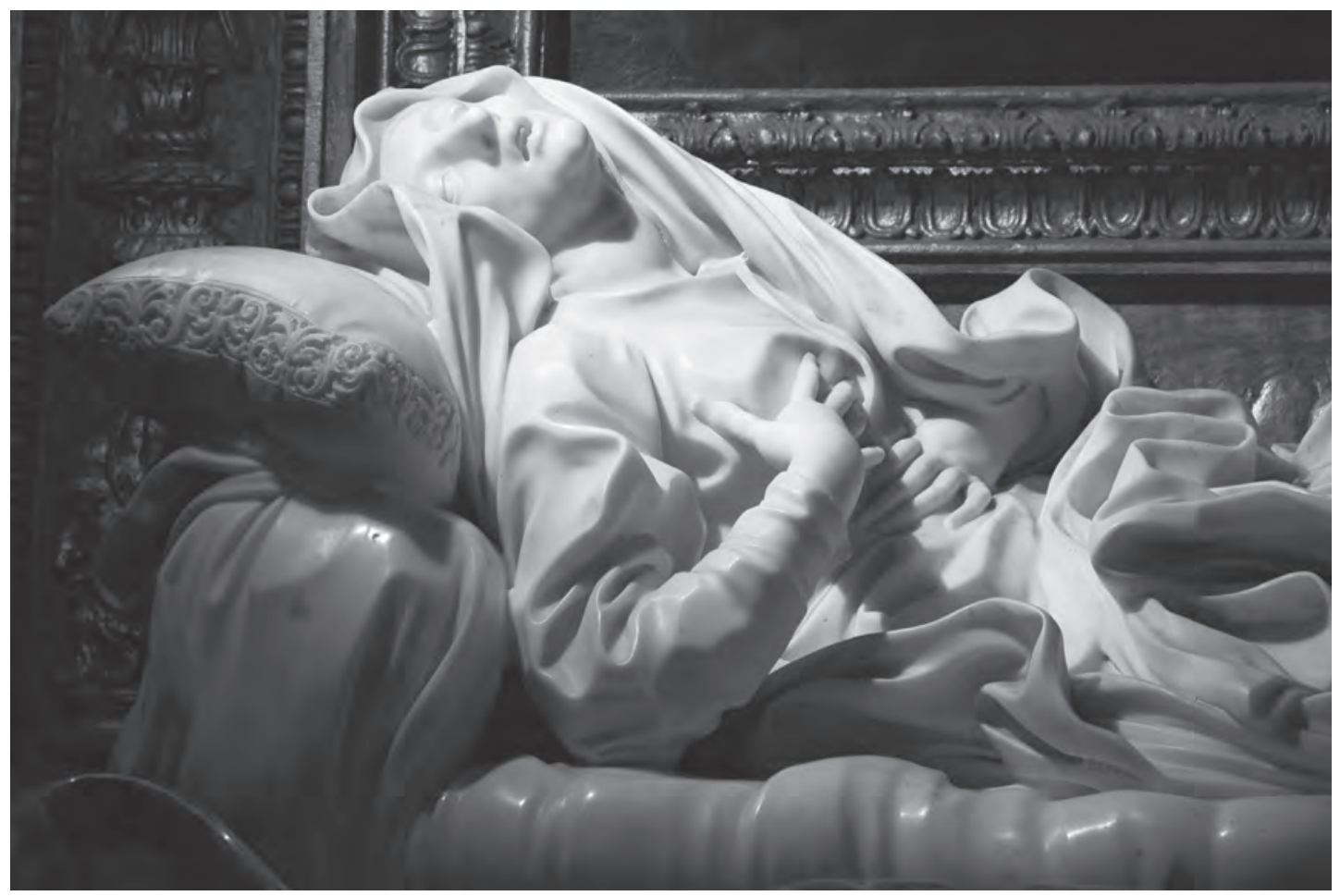

Logo, a essência da arte barroca não estaria fundamentada em seu compromisso, indiscutível, com a Contrarreforma (Weisbach, 1948), ou com o absolutismo monárquico, ou qualquer outra estrutura de poder dos séculos XVII e XVIII. Apesar de apresentar-se, inevitavelmente, como instrumento de propagação dos regimes autoritários, teria como princípio essencial o desenvolvimento de enérgicas e eficazes técnicas de comunicação. Por isso, serviria, de igual modo, à Igreja romana, às monarquias, às colônias e até mesmo às nações burguesas e aos países protestantes, como hoje tantos críticos apoiam (CHECA, MORÁN, 2001, p. 302). A técnica gestual da persuasão objetivava, por conseguinte, dirigir os comportamentos, conduzir os seres hu-

Figura 2 • Êxtase da Beata Ludovica Albertoni, escultura de Bernini (15981680), de 1674, inserida em uma das capelas à esquerda da nave da Igreja de San Francesco a Ripa, em Roma. Fonte: Fotografia do autor, 2007

Cadernos de Arquitetura e Urbanismo, v.18, n.22, $1^{0}$ sem. 2011 


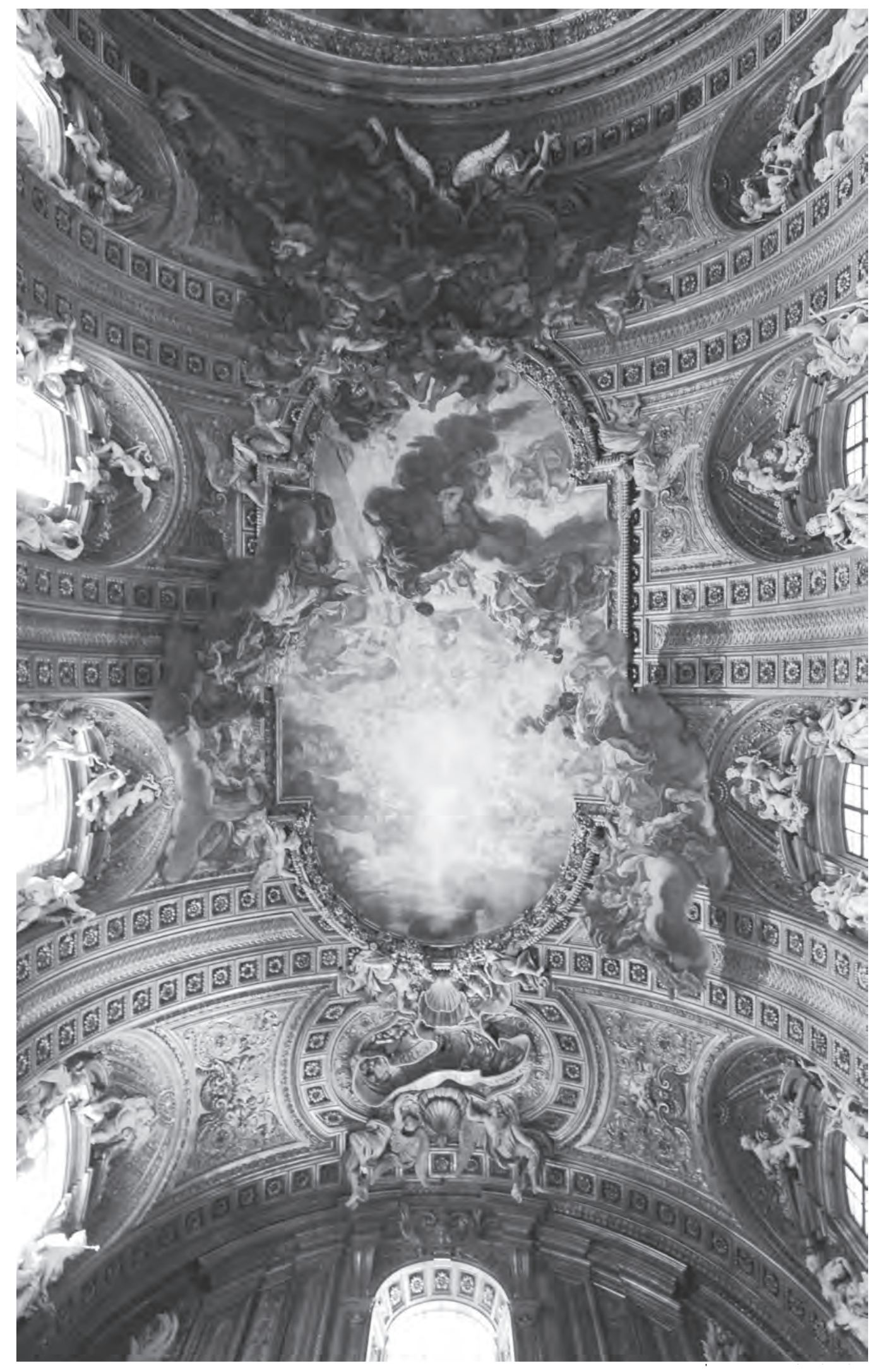


manos e as sociedades àquele modo de agir que seria pertinente à conservação da ordem, à preservação da delicada hierarquia estamental alcançada (sua essência, contudo, não residindo na submissão aos regimes, mas na comunicabilidade das obras, na persuasão propriamente dita).

Logo, seria possível afirmar que a cultura barroca teria organizado um aparelho de comunicação que buscava constituir e apresentar uma produção estética que fosse acessível a todos, que servisse para persuadir tanto as pessoas mais cultas, como a plebe ignorante e humilde; nesse sentido, suas expressões retomariam o caráter democrático que seria comum para a arte medieval e que havia sido abandonado pela erudição exacerbada de muitas das criações do Renascimento e do Maneirismo. O importante é que fosse feita a comunicação. Portanto, o discurso retórico seria desenvolvido de acordo com a técnica gestual escolhida, em consonância com o sistema de domínio a que estaria compromissado e dirigido a uma classe e a um público específicos. Por isso, o Barroco anteciparia as primeiras concepções do behaviorismo, ao trabalhar o estímulo e o controle da dimensão psicológica do homem. Maravall acrescentaria:

De certo modo e à distância, o Barroco antecipa a primeira concepção de um behaviorismo, quando trata de alcançar a posse de uma técnica de conduta fundada em uma intervenção sobre os recursos psicológicos que a movem: podemos traçar os movimentos do homem, estando atentos ao jogo de suas peças. "O homem - pensava La Rochefoucauld - acredita conduzir-se a si mesmo, quando, na realidade, é conduzido." Voltamos a entrar em contato aqui com uma nova referência a um racionalismo metódico, segundo o qual se supõe que seja possível dominar e reger uma massa de indivíduos, se conhecemos em seus elementos a sua natureza: por essa via, é possivel apoderar-se do controle dos recursos humanos e aplicá-los na condução dos homens, impulsionando-os na linha de uma crença, ou melhor, de uma ideologia e de certas maneiras de conduta que naquela se traduzem e em correspondência com o sistema de interesses sociais que a inspira (MARAVALL, 2007, p. 155) (tradução nossa).

As palavras do pensador francês seiscentista La Rochefoucauld (1613-1680), citadas por Maravall, revelam a consciência coetânea da submissão, frequentemente involuntária, a que as sociedades estavam submetidas devido aos mecanismos de propaganda dos regimes. Como afirmava o historiador espanhol, a montagem do aparato da persuasão passaria por uma estratégia de organização absolutamente racionalizada, o que poderia parecer um paradoxo, já que a experiência estética barroca se ofereceria, muitas vezes, por meio de um esquema compositivo completamente irracional. Mas a contradição só existiria superficialmente, pois o caráter ilógico da arte do período era conscientemente incentivado como artifício de conquista, de sedução. Objetivamente se sabia que as tensões, as dúvidas, as incertezas, as expectativas geradas pelo sentido inatural da forma prendiam a atenção e contribuíam para provocar aquela sensação de estupor, aquela impressão da maravilha tão essencial para o fim da persuasão. Certamente, o irracionalismo barroco derivava das 
experimentações dolorosas da difícil etapa maneirista da história da arte. Mas, na fase subsequente, o afastamento da razão não se daria como um caminho para a representação de um universo em colapso; pelo contrário, cientes da força expressiva deflagrada pelo furor desesperado da estética quinhentista, os artistas barrocos usariam racionalmente a tensão irracional maneirista com o escopo de suscitar o arrebatamento, o envolvimento, a conquista (a comunicabilidade eficiente da forma e da imagem dirigidas ao espectador).

Por meio dessa ação racional que buscava suscitar o encantamento, as instituições promoveriam o controle dos comportamentos e a exportação de suas mensagens que deveriam ser assimiladas pela massa com incondicional anuência; com temor e respeito, mas, ao mesmo tempo, com deleite e prazer. E o processo pedagógico da catequese pelas artes, da absorção das doutrinas por meio do discurso, passaria por um mecanismo que Maravall (2007, p. 153) viria a designar como um dirigismo dinâmico pela ação, em oposição ao que antes era praticado e que poderia ser compreendido como um dirigismo estático pela presença. Para o historiador, até o século XVI, ou seja, em todo o mundo clássico, bem como na Idade Média e nos primórdios do humanismo renascentista, a fé na verdade eterna, na estrutura perfeita do cosmos (seja a presença de um universo organizado regido por leis racionais, ou uma dimensão espiritualizada comandada pela esfera divina, pela presença de Deus) era tão absoluta que bastava expor aos receptores das mensagens os fatos inabaláveis para a verdade ser satisfatoriamente apreendida.

O homem barroco não poderia acreditar, obviamente, nesse dirigismo estático estimulado pela simples presença da verdade. Uma cultura tão consciente da grave crise que estava solidamente conformada, tão desiludida frente à incapacidade moral dos indivíduos e das sociedades, uma cultura tão pragmática e tão envolvida em sua necessidade de persuadir não arriscaria a ingênua assimilação passiva dos princípios essenciais da existência, princípios assegurados pelas classes dominantes. Não que o homem barroco desconfiasse da natureza, negasse a estrutura organizativa do cosmos, recusasse as leis do conhecimento racional: a ideia da transgressão fundada na contestação da ordem, no afastamento em relação àquela suposta harmonia universal, tão essencial para a crise do século XVI, tão fatal na caracterização do mundo maneirista (que vislumbrava o universo como uma nuance do caos), havia sido superada no período barroco com o nascimento da ciência e do pensamento modernos. Os dogmas existiam e eram indiscutíveis; porém deveriam ser expostos às massas por meio de um dirigismo dinâmico, de um severo controle regido pela ação.

Ou seja, os representantes eruditos da alta cultura barroca estavam cônscios da incapacidade dos menos favorecidos e de alguns setores da classe burguesa (o grande público) em capturar integralmente as teorias que amparavam e legitimavam as estruturas de domínio e poder que comandavam politicamente a sociedade da época. Por isso sabiam que era mais importante atraí-los pelos artifícios da propaganda e da persuasão do que tentar apresentar-Ihes as verdades inabaláveis do sistema; preceitos que não poderiam ser decididamente assimilados pelos grupos sociais, compreendidos pela massa de ignorantes. É 
nesse sentido que, para a cultura religiosa barroca, ao não se preocupar em contemplar e descrever a lógica providencial do Universo e sim ao se dedicar obsessivamente em dirigir as escoIhas e os comportamentos humanos, persuadir era muito mais importante do que demonstrar (ARGAN, 2004, p. 37).

No entanto, não só para as instituições religiosas dos séculos XVII e XVIII persuadir era mais importante que demonstrar. Para todas as organizações totalitárias e absolutistas barrocas, representadas especialmente pela Igreja e pelo Estado, o incentivo à ação propriamente dita por meio da propaganda, sobrepor-se-ia (e, repetidas vezes, chegaria mesmo a anular) o interesse pela demonstração e pelo estímulo ao conhecimento das verdades dogmáticas e especulativas do universo (material e divino): o importante era viver de acordo com os desígnios da religião e das nações, participar da jornada espiritual com fervorosa devoção, oferecer absoluta obediência à política do soberano (independente da assimilação do profundo sentido existencial oriundo das doutrinas religiosas e laicas).

Assim a salvação e a própria felicidade estavam diretamente vinculados à atitude dos fiéis e dos vassalos de suporte à política religiosa e à política do Estado. Os sistemas precisavam condicionar os comportamentos e as ações dos indivíduos; por isso era de importância capital a compreensão das especificidades de cada classe social (particularmente aquelas mais distantes do vértice da pirâmide, mas propensas a revoltas); conhecer suas nuances, seus anseios, apontar os maiores perigos impressos na força contida das massas, nas tendências de contestação da ordem social que poderiam gerar a explosão, repentina, de graves insurreições. A etapa subsequente seria, justamente, a implantação do processo de condução dos grupos sociais por meio dos artifícios da retórica artística e da persuasão, ou seja, coibir a sensação geral de insatisfação por meio da atração, do encanto, do envolvimento provocado pela intensa habilidade comunicativa das manifestações estéticas do Barroco; promover uma grande reviravolta na qual a energia aprisionada da população reprimida seria canalizada para a defesa e para a conservação da ordem.

Logo, era essencial entreter os indivíduos a todo instante para que não tivessem tempo nem desejo de se revoltar contra o sistema, eliminando a necessidade de prover qualquer melhoria na qualidade de vida dos crentes e dos súditos. Desse modo, o público era manipulado para acreditar nos regimes autoritários e assumir uma postura ativa de sustentação da ordem e da hierarquia política e religiosa, agitando as mentes dos espectadores, acionando-as em direção ao apoio obtuso ao monarca e à Igreja, promovendo a unânime aceitação da incondicional e inabalável autoridade histórica e religiosa dos regimes. A conquista do público seria perseguida por meio da administração dos desejos, dos afetos dos homens, oferecendo-lhes um espetáculo de atrações que deveria ser desvelado a todo instante e por todos os lados; espetáculo que os satisfazia, os agradava e que atribuía à plateia a falsa ilusão de que tinha alguma relevância, a fantasia de que detinha algum poder de participação nos acontecimentos políticos e religiosos da sociedade. A turba não precisava ser só arrefecida, precisava ser manipulada para adquirir a ingênua alucinação de ser cúmplice daquele poder que paradoxalmente a subjugava; e isto só era possível pelo despertar das vontades dos espectadores, conseguido pelos go- 
vernos ao darem atenção especial às estratégias de persuasão das massas, oferecendo a elas a oportunidade de sentir orgulho e devoção frente à Igreja e ao Estado.

Por outro lado, já foi dito anteriormente que a cultura barroca apresentava um caráter absolutamente conservador. Não obstante, no cenário geral de crise, para conservar a ordem e manter inabalável a estrutura hierárquica de poder, para não permitir qualquer alteração na pirâmide estamental, para afastar do organismo social todo desejo e toda a possibilidade de inovação, as classes dominantes abririam caminho, paradoxalmente, ao exercício da inovação em alguns setores que não ofereceriam risco à frágil composição do status quo. É lógico que essa atitude não poderia ser compreendida como uma benevolente concessão oferecida pelos governantes e pela Igreja à liberdade de expressão, e sim como uma clara necessidade de incrementar a tática de controlar as mentes pela propaganda barroca, de reforçar a condução das massas por meio dos artifícios da retórica e da persuasão, de afastá-las dos riscos de inovação da hierarquia social e política. ${ }^{6}$

Ou seja, poderia se dizer que, no Barroco, os fins justificam os meios. A frase clássica de Maquiavel (1469-1527), mesmo proferida fora daquele contexto particular de crise que viria a se constituir no século XVII, representa, com muita clareza, a contradição entre a ousadia técnica e expressiva das criações barrocas, seu caráter original, inovador e revolucionário, e a obsessiva busca pela conservação da tradicional organização social agenciada pelas estruturas contemporâneas de poder (figuras 3 e 4). No contexto da história da arte, somente no Barroco essas palavras se adequariam perfeitamente à produção estética; exatamente devido à consciência que os príncipes, os reis, os imperadores, os primeiros ministros, os religiosos absorveram de que o novo, mesmo podendo ser perigoso, atraía, e devia ser utilizado como meio para a conquista dos corações. Todas as artes acabariam se beneficiando dessa via aberta à experimentação, e certamente as manifestações barrocas mostrar-se-iam incrivelmente libertas em seus meios de expressão, desde que sua composição estética, seu conteúdo e sua forma não ameaçassem minimamente a estrutura dos governos absolutistas e da religião católica. É só lembrar como a grande maioria das restrições à arte promovidas pelos decretos tridentinos no período maneirista foram praticamente ignoradas nos séculos XVII e XVIII. Maravall concluiria:

Por isso o Barroco, para ser conservador, declara-se muitas vezes inovador. Era preciso aceitá-lo assim, precisamente para melhor controlar todo o movimento dessa última natureza, em sua direção e em seus limites. Nesses setores nos quais nem politicamente nem intelectualmente resultava qualquer perigo, era preciso deixar as portas abertas à novidade, devia se fazer muito ruído em torno dela para atrair a atenção das pessoas e, nesses terrenos, devia levá-la ao extremo para saciar seu apetite: a irrupção de extravagâncias em poesia, em literatura, nas artes, etc., compensa a privação de novidade em outras partes. Assim, pois, o virtuosismo da novidade, característico do Barroco nos campos nos quais ela não possui força corrosiva, explica-se por certas motivações sociais muito diretas (MARAVALL, 2007, p. 291-291) (tradução nossa).
6. Giovanni Botero (1533-1617) filósofo italiano e um dos principais teóricos da razão do Estado, dizia precocemente, em 1589: "Já que o povo é, por natureza, instável e desejoso de novidade, acontece que, se não é contido de várias formas pelo seu Príncipe, procura essa novidade por si mesmo com a mutação do Estado e do governo; por isso, todos os príncipes avisados introduziram alguns entretenimentos populares que, quanto mais servirem para se exercer a virtude do espírito e do corpo mais adequados serão..." (BOTERO apud VILLARI, 2005, p. 111) (tradução nossa). 


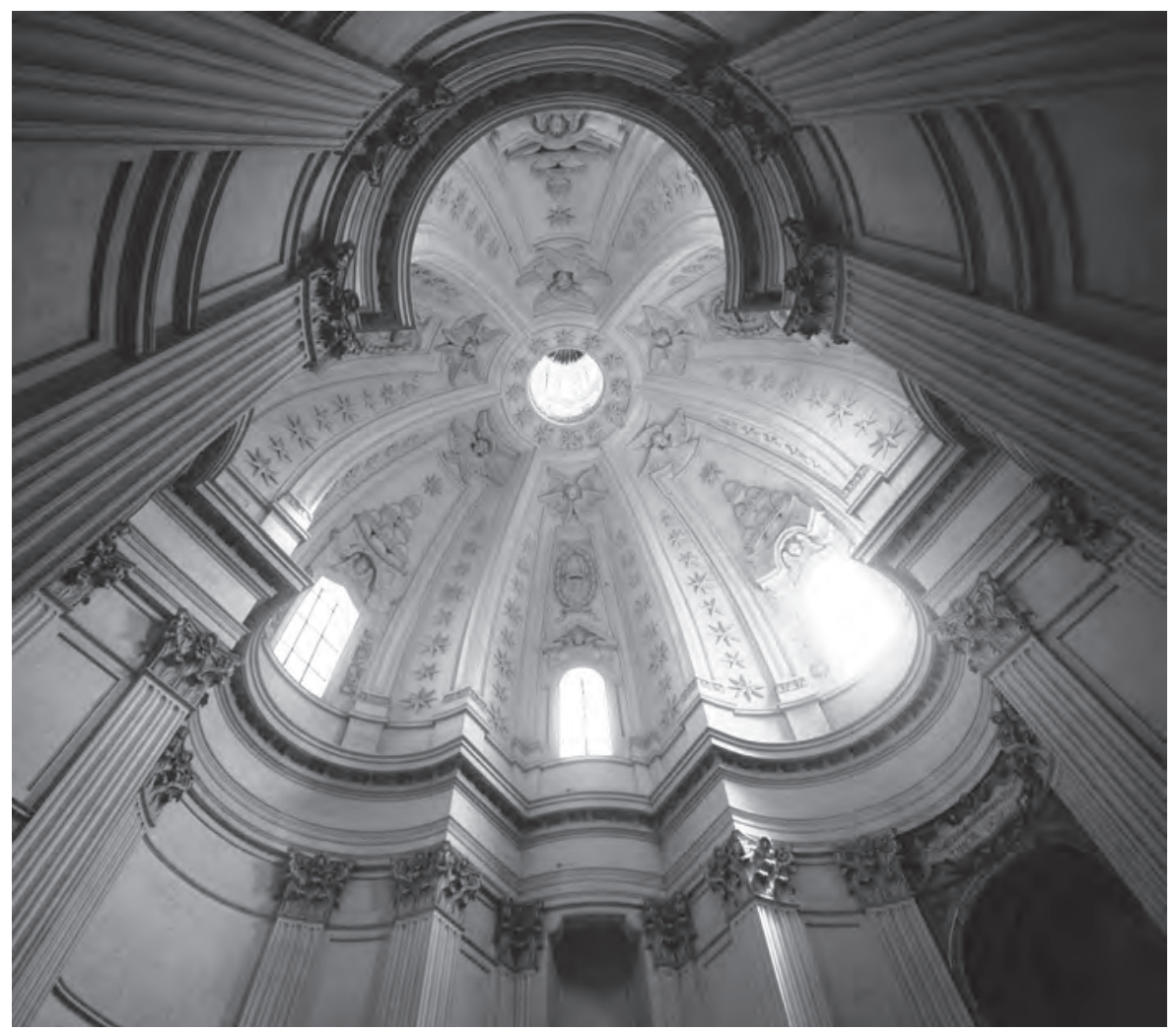

Figura 3 • Cúpula da Igreja de Sant'Ivo alla Sapienza, assentada ao fundo do pátio da antiga Universidade de Roma. O complexo desenho do corpo da igreja, formado por elementos côncavos expansivos em oposição a setores espaciais convexos, transformarse-ia, virtualmente, em uma perfeita circunferência no óculo de entrada de luz da lanterna. Projetada e construída por Francesco Borromini (1599-1667) entre 1642 e 1650. Fonte: fotografia do autor, 2007

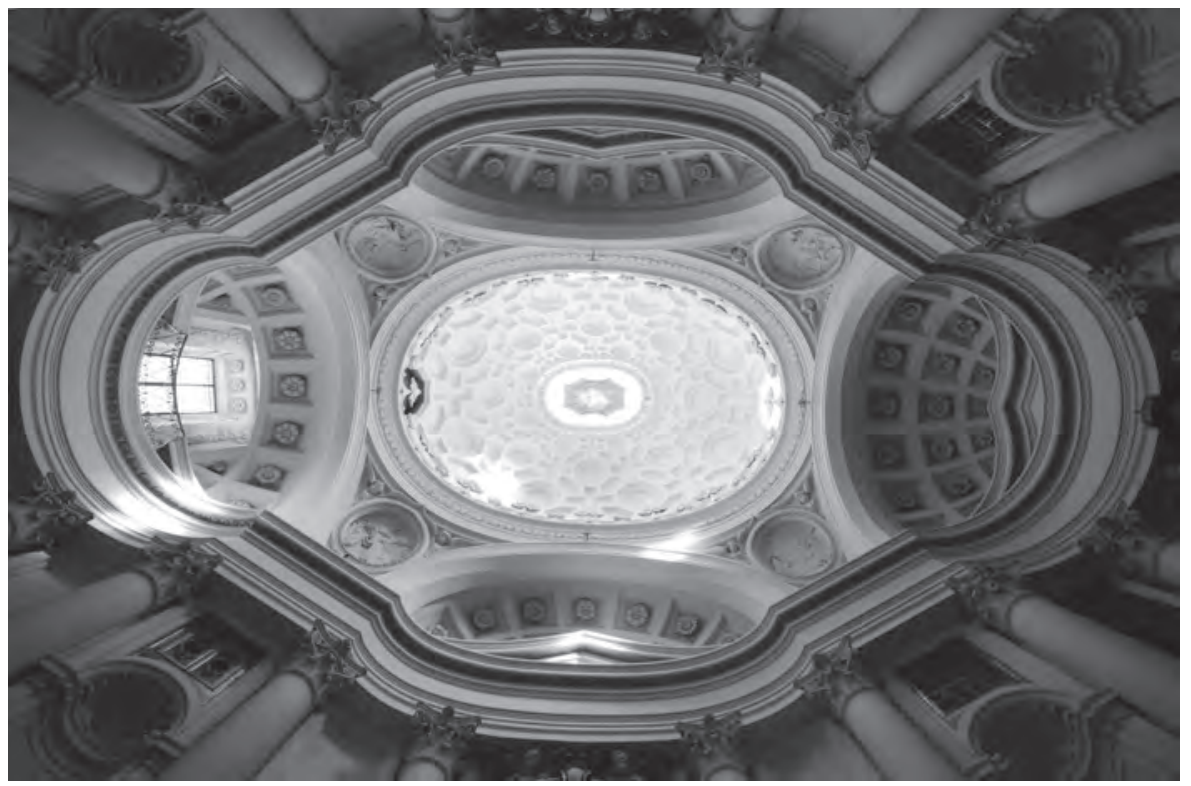

Figura 4 • Roma. Abóbada da Igreja de San Carlo alle Quattro Fontane, edifício construído por Francesco Borromini entre 1638 e 1641. A configuração espacial de San Carlino seria formada pela interpenetração de pelo menos cinco estruturas volumétricas distintas, entre capelas, presbitério, coro e a própria nave, de configuração elíptica. Nunca antes havia sido elaborado um interior tão complexo em uma extensão espacial tão exígua. Fonte: Fotografia do autor, 2011. 


\section{Referências}

ARGAN, Giulio Carlo. Immagine e persuasione. Milano: Feltrinelli, 1986.

ARGAN, Giulio Carlo. L'Europa delle capitali. Milano: Skira, 2004.

BATTISTINI, Andrea. II Barocco: cultura, miti, immagini. Roma: Salerno, 2002.

CHECA, Fernando; MORÁN, José Miguel. El Barroco. Madrid: Istmo, 2001.

CROCE, Benedetto. Storia dell'età barocca in Italia. Milano: Adelphi, 1993.

D'ORS, Eugenio. Du Baroque. Paris: Gallimard, 1968.

HAUSER, Arnold. História social da arte e da literatura. São Paulo: Martins Fontes, 1998.

MARAVALL, José Antonio. La cultura del Barroco. Barcelona: Ariel, 2007.

PARKER, Geoffrey. II soldato. In:VILLARI, Rosario (org.). L'uomo barocco. Roma-Bari: Laterza, 2005.

VILLARI, Rosario (org.). L'uomo barocco. Roma-Bari: Laterza, 2005.

WEISBACH, Werner. EI Barroco, arte de la Contrarreforma. Madrid: Espasa-Calpe, 1948.

\section{Endereço para correspondência}

Rodrigo Espinha Baeta

Rua Francisco Rosa, 500 / 206 / A

Bairro Rio Vermelho

41940-210 - Salvador-BA

E-mail:rodrigobaeta@yahoo.com.br 